\title{
Awareness and use of folic acid among reproductive age and pregnant women
}

\section{Üreme çağında ve gebe kadınlarda folik asit hakkında bilgi düzeyi ve kullanım durumu}

\author{
Gülengül N. Köken ${ }^{1}$, Aysel Uysal Derbent ${ }^{2}$, Onur Erol' ${ }^{2}$, Nimet Saygın², Hülya Aylk², Mehmet Karaca² \\ ${ }^{1}$ Department of Obstetrics and Gynaecology, Faculty of Medicine, Afyon Kocatepe University, Afyonkarahisar, Turkey \\ ${ }^{2}$ Department of Obstetrics and Gynaecology, Antalya Education and Research Hospital, Antalya, Turkey
}

\section{Abstract}

Objective: Folic acid supplementation during the pre-conception period and first trimester of pregnancy reduces the incidence of neural tube defects (NTDs). In this study, our aim is to investigate knowledge and use of folic acid among women attending our clinic.

Material and Methods: Between January 2012 and June 2012, 817 participants, consisting of 345 pregnant and 472 non-pregnant women, were enrolled in this survey. A questionnaire including socio-demographic information, knowledge and use of folic acid was applied. Results: $48.2 \%$ of participants were aware of folic acid for the prevention of congenital anomalies. Knowledge and use of folic acid increase with socio-economic status and educational level. Participants who were already knowledgeable about folic acid cited health care professionals as common sources of information. Although $88.2 \%$ of the pregnancies were planned among the currently pregnant women, only $14.2 \%$ of them stated that they had used folic acid in the pre-conception period. The use of folic acid during the first trimester among pregnant women was $48.6 \%$. Furthermore, $18.4 \%$ of participants had not used folic acid and $29.3 \%$ of them had not remembered whether they had or not. Even though $94.4 \%$ of health care professionals had heard about folic acid, $28.3 \%$ reported that they had used folic acid before pregnancy.

Conclusion: It is thought that there is a relatively high incidence of NTD in Turkey, which is due to inadequate information about NTDs and the use of folic acid. Primarily health care professionals such as midwives, nurses and family physicians should aim to inform all reproductive age women about folic acid for the prevention of NTDs, who should be encouraged to take the supplement when planning pregnancy. (J Turkish-German Gynecol Assoc 2013; 14: 87-91)

Key words: Folic acid, neural tube defect, pregnancy

Received: 09 January, 2013

Accepted: 24 April, 2013

\section{Özet}

Amaç: Perikonsepsiyonal dönemde ve 1. trimester boyunca folik asit desteği nöral tüp defektini (NTD) azaltmaktadır. Çalışmamızda hastanemize muayene için gelen üreme çağındaki hastalar ile birlikte gebe kadınların folik asit kullanımını ve bunlara etki eden faktörleri araştırmayı amaçladık.

Gereç ve Yöntemler: Ocak 2012- Haziran 2012 tarihleri arasında hastanemiz Kadın Hastalıkları ve Doğum polikliniğine gelen 817 hastaya (345 gebe, 472 gebe değil) sosyodemografik bilgiler ve folik asit kullanımı ile ilgili soruları içeren bir anket uygulandı.

Bulgular: Hastaların \% 48.2'si folik asidin doğumsal anomalileri önlediğini bildirmiştir. Folik asit hakkındaki bilgi ve kullanımı ekonomik düzey ve eğitim düzeyi ile artmaktadır. Katılımcılar folik asit hakkındaki bilgileri en fazla sağlık çalışanlarından öğrendiklerini belirtmiştir. Gebe katılımcılar arasında, gebeliklerin \% 88.2'i planlı olmasına rağmen sadece \% 14.2'de prekonsepsiyonel dönemden başlayarak folik asit kullanılmıştır. Gebeliğin ilk 3 ayında folik asit kullanım oranı ise \% 48.6'dır. Gebeliğin hiçbir döneminde folik asit kullanmayanlar \% 18.4, kullanıp kullanmadığını bilmeyenler ise \% 29.3'dür. Çalışmaya katılan sağlık çalışanlarının \% 94.4'ü folik asidi bilirken, bunların \% 28.3'de gebelik öncesinde folik asit kullandıkları saptandı.

Sonuç: Ülkemizde NTD sıklığının göreceli olarak yüksek olduğu düşünüldüğünde doğurganlık dönemindeki kadınların NTD ve folik asit kullanımı hakkında yeterli bilgiye sahip olmadıkları, bu konuyu iyi bilen sağlık çalışanlarının ise gebelik öncesi dönemde yüksek oranda folik asit kullanmadıkları görülmüştür. Gebelik öncesi folik asit kullanımının azlığı, üreme çağındaki kadınların folik asitle ilgili daha ayrıntılı bilgilendirilmeleri gerektiğini düşündürmektedir. Bu amaçla öncelikle ebe, hemşire ve aile hekimleri gibi hastaların ilk etapta ulaşacağı sağlık personelinin hastaları bilgilendirme yönünde eğitilmesi ve bu kişilerin, doğurganlık çağındaki tüm kadınlara NTD'nin önlenmesinde folik asidin etkisinin duyurulması için çalışmalar yapmaları gerekmektedir. (J Turkish-German Gynecol Assoc 2013; 14: 87-91)

Anahtar kelimeler: Folik asit, nöral tüp defekti, gebelik

Geliş Tarihi: 09 Ocak 2013

Kabul Tarihi: 24 Nisan 2013

\section{Introduction}

Folic acid, also called folate in its nature form, is a form of water soluble vitamin B9. It is found in green leafy vegetables (broccoli, spinach, lettuce, romain lettuce) and some fruits (orange, banana). It is the coenzyme that transfers single carbon groups for nucleic acid and amino acid metabolism. Folic acid has an important role in DNA/RNA synthesis, amino acid transformation, the formation of red blood cells, and the formation and maintenance of the body cells. Folic acid require- 
ments increase during periods of rapid growth and division of the body's cells throughout life $(1,2)$.

The term neural tube defects (NTDs) refers to any malformation of the embryonic brain and/or spinal cord. During the embryogenesis period, the brain and spinal cord originate from the neural tube. Methionine is essential for neural tube development. In folic acid deficiency, homocysteine cannot be converted to methionine; as a result, homocysteine levels increase, and methionine levels remain lower. Due to increased homocysteine levels in folic acid deficiency and cardiovascular diseases, NTDs like anencephaly and spina bifida may develop. The failure of neural tube closure prior to the end of the fourth week of embryogenesis causes NTDs. Genetic and environmental factors play an important role in the aetiology of NTDs $(3,4)$.

Studies show that the supplementation of $0.4 \mathrm{mg}$ folic acid during the periconceptional period prevents $50-70 \%$ of NTDs $(5,6)$. Normal dietary intake meets half of the daily folic acid requirement (7). As a consequence, since the early 1990s, health authorities in many developed countries have recommended that all women planning to become pregnant should consume additional dietary and supplementary folic acid periconceptionally (8-12).

We aimed to determine awareness, knowledge and use of folic acid and the factors that affect folic acid intake among Turkish women.

\section{Material and Methods}

The cross-sectional survey was conducted at the Department of Obstetrics and Gynecology, Antalya Teaching and Research Hospital, from January 2012 to June 2012. Participants consisted of 345 pregnant women admitted to the antenatal clinic, and 472 non-pregnant women including hospital staff and patients admitted to the gynaecology clinic with a variety of complaints. A questionnaire that consisted of 19 questions was applied by doctors for randomly selected women aged 19-45 years. Demographic characteristics (age, marital and socioeconomic status, educational level), obstetric history (previous pregnancy number, child with neural tube defect), knowledge about folic acid and NTD, the use of folic acid during the periconceptional period, source of information regarding folic acid were questioned. Awareness was assessed by respondents having 'heard or read' about folic acid. Knowledge about folic acid was defined as knowing that folic acid prevents NTDs. Data were analysed using SPSS version 11.0 (SPSS Inc. Chicago, USA). The Ethical Committee of our hospital approved the study. All participants provided written informed consent.

\section{Results}

The total number of women included in the study was 817 . The mean age of the women was 32.4 ( $\mathrm{SD} \pm 8.19$ ) years. $92.9 \%$ of participants were married and 22\% (180 women) were health care professionals. $60 \%$ of pregnant women were multiparous compared to $75 \%$ of non-pregnant women. Pregnancies were planned in $88.2 \%$ of the currently pregnant women; the mean gestational age at enrolment was $27.5(\mathrm{SD} \pm 9.7)$ weeks.
Demographic characteristics of the women participating in the study are given in Table 1 .

Three hundred and forty five of the women (42.2\%) reported that they had heard about folic acid and 394 (48.2\%) of them stated that folic acid could prevent birth defects; however, only $150(18.3 \%)$ women could specify its role in preventing NTDs. Knowledge and the use of folic acid was associated with educational level (Figure 1). 18.4\% of participants stated that they had not used folic acid at any time during pregnancy and $29.3 \%$ of them did not remember whether they had used folic acid or not (Figure 2). Knowledge of folic acid was lowest among women aged $35-49$ years (30.8\%) and highest among women aged 25-34 years $(45 \%)$. The proportion of women using periconceptional folic acid was $21.1 \%$. Doctors were the most frequent source of information (76.6\%), but other sources of information were relatives/friends (19.9\%) and the media (3.5\% -television/magazine/ internet).

Among the pregnant women, 225 (65.7\%) of them reported that they had heard about folic acid; initiation of folic acid intake at least one month before conception and during the first trimester was seen in 14.2\% (49 women) and 48.6\% (168 women), respectively. $94.4 \%$ of health care professionals were aware of folic acid; nevertheless, only $28.3 \%$ reported that they had used folic acid before pregnancy.

12 of the participants had a history of a foetus with NTD. Among these, only $25 \%$ of them had taken folic acid before pregnancy, $75 \%$ of them had never used the supplement or had been informed about the need for supplementation of folic acid during pregnancy.

Table 1. Demographic characteristics of the women

\begin{tabular}{|c|c|c|}
\hline & $\mathbf{n}$ & $\%$ \\
\hline \multicolumn{3}{|l|}{ Age (years) } \\
\hline$<25$ & 159 & 19.4 \\
\hline $25-34$ & 356 & 43.5 \\
\hline$>35$ & 302 & 37.1 \\
\hline \multicolumn{3}{|l|}{ Education } \\
\hline Illiterate & 14 & 1.9 \\
\hline Primary & 266 & 32.5 \\
\hline Secondary & 126 & 15.4 \\
\hline High school & 166 & 20.3 \\
\hline University and above & 245 & 29.9 \\
\hline \multicolumn{3}{|l|}{ Currently pregnant } \\
\hline Yes & 345 & 42.2 \\
\hline No & 472 & 57.8 \\
\hline \multicolumn{3}{|l|}{ Marital status } \\
\hline Married & 759 & 92.9 \\
\hline Single & 58 & 7.1 \\
\hline \multicolumn{3}{|l|}{ History of NTD } \\
\hline Yes & 12 & 1.5 \\
\hline No & 805 & 98.5 \\
\hline
\end{tabular}




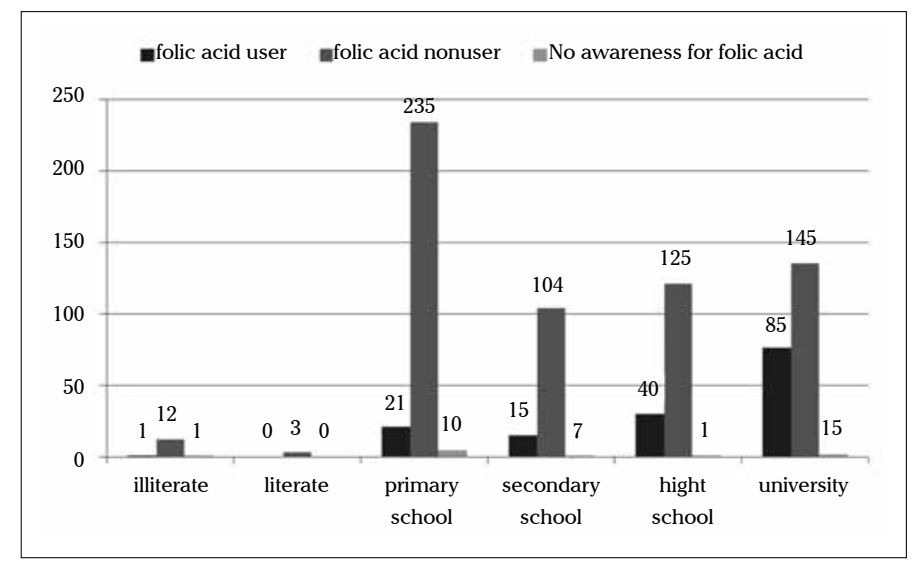

Figure 1. Distribution of educational level among folic acid users

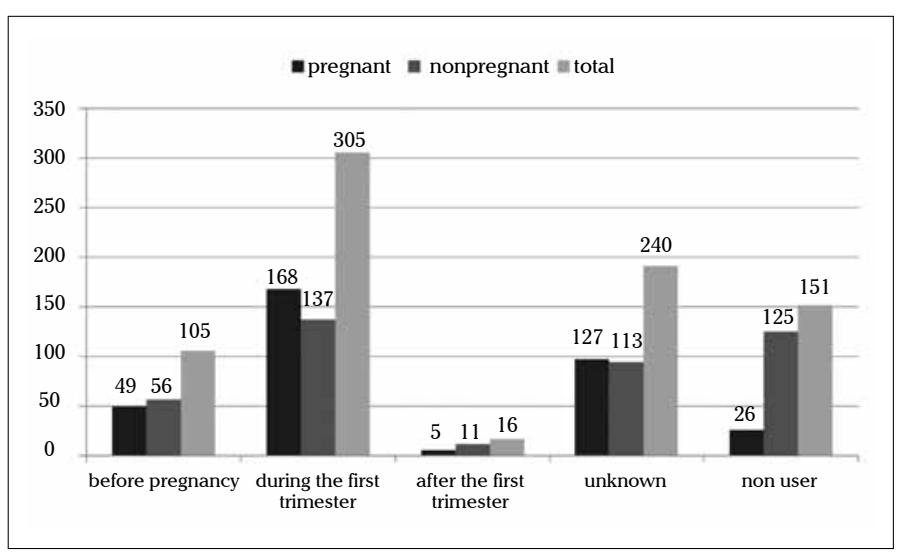

Figure 2. Distribution of folic acid intake among participants

\section{Discussion}

The prevalence of NTD varies in the ranges 0.4-1.6, 2-4, 2.9-5.2, 4-9 per 1000 live births in the European countries, in the USA, in the Middle Eastern countries, and in Turkey, respectively (13, 14). To increase the awareness of genetic disorders among health care personnel, the Turkish Ministry of Health issued a guideline in 2002. This guideline recommends daily folic acid supplement for all women of childbearing age before conception and throughout the first trimester (15). When the economic situation and high incidence of NTD in Turkey is considered, the prevention of these malformations is particularly important. In this study, levels of awareness, knowledge, and the use of folic acid periconceptionally were found to be $42.2 \%, 18.3 \%$ and $21.1 \%$, respectively. Socio-economic and educational level caused a geographical distribution regarding awareness of folic acid in Turkey. A cross-sectional study conducted in Konya reported that only $22 \%$ of participants were aware of folic acid, and that $13 \%$ of them indicated knowledge about the relationship between folic acid supplementation and NTD prevention (16). Another study conducted in Edirne reported that $18.6 \%$ of the subjects had heard of folic acid, but only $6.4 \%$ of them knew about its preventive role against NTDs and $1 \%$ of them had taken folic acid prior to conception (17). A pilot study on a community-based training programme highlighted the importance of informing the population about folic acid. A regional campaign was organised to create awareness among women in Izmir. Before the campaign was carried out, $18 \%$ of women had heard of folic acid; their level of knowledge increased after the campaign (18). Another cross-sectional study that was carried out in Kayseri reported the awareness of folic acid as $46.3 \%$, the use of folic acid periconceptionally as $12.2 \%$, and knowledge about folic acid as $6.3 \%$ (19). The trend in other countries is different, with reports of folic acid awareness rate as high as $53.7 \%$ in Arabia, $24.4 \%$ in Thailand, $35.8 \%$ in China, 95\% in Canada (20-23).

In total, $65.7 \%$ of pregnant women in our survey had heard of folic acid, and $14.2 \%$ of them had taken folic acid during the whole protective period. However, this correct folic acid taking rate during the recommended period in pregnant women was lower than the rate from developed countries (24-26). Another considerable finding in our study was that the use of folic acid among health care professionals (28.3\%) preconceptionally was lower than expected. This suggests that an awareness of folic acid does not necessarily increase periconceptional use of folic acid supplements.

The risk of NTD recurrence in subsequent pregnancy is $2-3 \%$ (5). No recurrence of NTD was reported in a study conducted on 190 women with a previous pregnancy with NTD who received $5 \mathrm{mg}$ folic acid per day during the periconceptional period. This study also pointed out that NTD recurrence was seen in $4.04 \%$ of the patients who had not used folic acid (27). Another study reported a rate of $72 \%$ reduction in recurrent risk of NTDs in women who received $4 \mathrm{mg}$ of folic acid per day during the periconceptional period (8).

Due to the fact that NTDs occur during the $22^{\text {th }}-28^{\text {th }}$ days of the embryonic period, before most women even know that they are pregnant, the initiation of folic acid supplements after the first month of pregnancy is too late to prevent NTDs. Thus, in 1992, the US Public Health Service recommended that all women capable of becoming pregnant consume at least 400 micrograms $(0.4 \mathrm{mg})$ of folic acid per day preconceptionally and continue throughout the first trimester (28). For women who had a previous pregnancy with an NTD, folic acid supplementation of $4 \mathrm{mg}$ per day during the same period is recommended (29). Despite these recommendations and national campaigns, periconceptional intake of additional folic acid remains very low in many countries $(30,31)$.

In recognition of the need to decrease the risk of NTDs, fortification programs were mandated in both the United States and Canada in 1998. The United States made folic acid fortification mandatory for bread and grain products at $0.14 \mathrm{mg}$ folic acid/100 g flour and $0.24 \mathrm{mg} / 100 \mathrm{~g}$ pasta (32). In Canada, fortification of flour and pasta was set at $0.15 \mathrm{mg}$ folic acid/100 g and $0.20 \mathrm{mg} / 100 \mathrm{~g}$, respectively. This fortification is estimated to meet $25 \%$ of the recommendation of folic acid (33). It is known that to improve public health, the enrichment of foods with folic acid is a very important approach in order to reduce the incidence of NTD. However, fortified foods are not sufficient for many women; also, there is no food fortification with folic acid in many countries, like Turkey. Supplementation of vitamins is needed to achieve the recommended daily dose (34). 
Despite numerous health benefits of folic acid supplementation, emerging evidence in recent years suggests that increased population exposure to folic acid may also have a negative impact with respect to certain developmental and degenerative disorders. For example, much attention is currently focused on the role of folic acid fortification augmenting colon cancer risk (35). A similar, perhaps unexpected negative effect has also been shown during pregnancy. Synthetic folic acid saturates human dihydrofolate reductase, leading to unmetabolised folate in circulation, possibly masking irreversible pernicious anaemia seen in $B_{12}$ deficiency. Low maternal vitamin $B_{12}$ and high folic acid status during pregnancy may contribute to insulin resistance and obesity in offspring (36).

The incidence of NTD is considerably higher in our country. These abnormalities are substantially preventable by the encouragement of folic acid usage. When comparing the studies from Turkey and other countries, a lack of information and the use of folic acid drew attention. Further efforts are needed to inform the population and promote the optimal use of folic acid supplements. Therefore, health care professionals should aim to instruct the effects of folic acid to all women of reproductive age for the prevention of NTDs. Additionally, it may be appropriate to inform patients who attend health care centres and distribute comprehensive brochures about folic acid. Public health campaigns can be arranged to announce the effect of folic acid on preventing NTDs. These campaigns should address health care professionals, and all women and men of reproductive age. Health professionals should consult all reproductive aged women about the importance of folic acid for the prevention of NTDs. Due to the fact that essential amounts of folic acid cannot be achieved by diet alone, daily folic acid supplementation should be given to women during the periconceptional period.

Ethics Committee Approval: Ethics committee approval was received for this study.

Informed Consent: Written informed consent was obtained from patients who participated in this study.

Peer-review: Externally peer-reviewed.

Author contributions: Concept - G.N.K.; Design - A.U.D.; Supervision - O.E.; Resource - H.A.; Materials - O.E.; Data Collection\&/or Processing - G.N.K., N.S.; Analysis\&/or Interpretation - A.U.D.; Literature Search - O.E.; Writing - O.E.; Critical Reviews - O.E.

Conflict of Interest: No conflict of interest was declared by the authors.

Financial Disclosure: No financial disclosure was declared by the authors.

\section{References}

1. Coskun A, Özdemir Ö. Evaluation of nutrition and mineral-vitamin use during pregnancy. J Turk Soc Obstet Gynecol 2009; 6: 155-70.

2. Çoşar E, Köken G, Köken R, Şahin FK, Yeşildağer E, Arıöz DT, et al. Neural tube defects and pregnancy. J Turk Soc Obstet Gynecol. 2009; 6: 193-6.
3. Tunçbilek E, Boduroglu K. Nöral tüp defektlerinin önlenmesi. Sürekli Tıp Egitimi Dergisi 1998; 7: 225-7.

4. Miner SE, Evrovski J, Cole DE. Clinic chemistry and molecular biology of homocysteine metabolism: an update. Clin Biochem 1997; 30: 189-201. [CrossRef]

5. American Academy of Paediatrics, Policy statement. Folic acid for the prevention of neural tube defects. Paediatrics September 1993; 92: 493-4.

6. Friel JK, Frecker M, Frase FC. Nutritional patterns of mothers of children with neural tube defects in Newfoundland. Am J Med Genet 1995; 55: 195-9. [CrossRef]

7. Czeizel AE. Primary prevention of neural tube defects and some other major congenital abnormalities: recommendations for the appropriate use of folic acid during pregnancy. Paediatr Drugs 2000; 2: 437-49. [CrossRef]

8. Prevention of neural tube defects: results of the Medical Research Council Vitamin Study. MRC Vitamin Study Research Group. Lancet 1991; 338: 131-7. [CrossRef]

9. Van Allen MI, Fraser FC, Dallaire L, Allanson J, McLeod DR, Andermann E, et al. Recommendations on the use of folic acid supplementation to prevent the recurrence of neural tube defects. Clinical Teratology Committee, Canadian College of Medical Geneticists. CMAJ 1993; 149: 1239-43.

10. Rasmussen LB, Andersen NL, Andersson G, Lange AP, Rasmussen $\mathrm{K}$, Skak-Iversen $\mathrm{L}$, et al. Folate and neural tube defects. Recommendations from a Danish working group. Dan Med Bull 1998; 45: 213-7.

11. Botto LD, Lisi A, Robert-Gnansia E, Erickson JD, Vollset SE, Mastroiacovo $\mathrm{P}$, et al. International retrospective cohort study of neural tube defects in relation to folic acid recommendations: are the recommendations working? BMJ 2005; 330: 571. [CrossRef]

12. Kondo A, Kamihira O, Shimosuka Y, Okai I, Gotoh M, Ozawa H. Awareness of the role of folic acid, dietary folate intake and plasma folate concentration in Japan. J Obstet Gynaecol Res 2005; 31: 172-7. [CrossRef]

13. Pérez-Escamilla R. Periconceptional folic acid and neural tube defects: Public health issues. Bull Pan Am Health Organ 1995; 29: $250-63$.

14. EUROCAT Working Group. 15 Years of Surveillance of Congenital Abnormalities in Europe 1980-1994. Report No. 7. Brussels: Scientific Institute of Public Health-Louis Pasteur, 1997; 50-79.

15. Tunçbilek E, Temel E, Özalp İ, Teziç T, Köse R, Üstündağ M, Haznedaroğlu D, Kaptan H. Genetic diseases. Handbook for health personnel 2002. T.C. Ministry of Health General Directory of Health Project, T.R. Ministry of Health General Directorate of Mother and Child Health and Family Planning, Ankara.

16. Unusan N. Assesment of Turkish women's knowledge concerning folic acid and prevention of birth defects. Public Health Nutr 2004; 7: 851-55. [CrossRef]

17. Yüce MA, Candaş T, Sayın NC, Balkanlı-Kaplan P, Güçer F, Yardım T. Olgularımızda gebelik öncesi ve gebelikte folik asit kullanımı. Türk Fertilite Dergisi 2001; 9: 251-7.

18. Turgul O, Anli N, Mandiracioglu A, Bati H, Akkol S. The regional campaign for women on awareness of neural tube defects and folic acid in Narlidere, Izmir: a community-based intervention. Eur J Contracept Reprod Health Care 2009; 14: 69-74. [CrossRef]

19. Baykan Z, Oztürk A, Poyrazoğlu S, Gün I. Awareness, knowledge, and use of folic acid among women: a study from Turkey. Arch Gynecol Obstet 2011; 283: 1249-53. [CrossRef]

20. Bener A, Al Maadid MG, Al-Bast DA, Al-Marri S. Maternal knowledge, attitude and practice on folic acid intake among Arabian Qatari women. Reprod Toxicol 2006; 21: 21-5. [CrossRef] 
21. Nawapun K, Phupong V. Awareness of the benefits of folic acid and prevalence of the use of folic acid supplements to prevent neural tube defects among Thai women. Arch Gynecol Obstet 2007; 276: 53-7. [CrossRef]

22. Ren A, Zhang L, Li Z, Hao L, Tian Y, Li Z. Awareness and use of folic acid, and blood folate concentrations among pregnant women in northern China-an area with a high prevalence of neural tube defects. Reprod Toxicol 2006; 22: 431-6. [CrossRef]

23. French MR, Barr SI, Levy-Milne R. Folate intakes and awareness of folate to prevent neural tube defects: a survey of women living in Vancouver, Canada. J Am Diet Assoc 2003; 103: 181-5. [CrossRef]

24. Forster DA, Wills G, Denning A, Bolger M. The use of folic acid and other vitamins before and during pregnancy in a group of women in Melbourne, Australia. Midwifery 2009; 25: 134-46. [CrossRef]

25. Bekkers RL, Eskes TK. Periconceptional folic acid intake in Nijmegen, The Netherlands. Lancet 1999; 353: 292. [CrossRef]

26. Morin P, De Wals P, St-Cyr-Tribble D, Niyonsenga T, Payette H. Pregnancy planning: a determinant of folic acid supplements use for the primary prevention of neural tube defects. Can J Public Health 2002; 93: 259-63.

27. Aydınlı K, Çağdaş A, Kayserili H, Kuseyri F, Tükel T, Eriş H, et al. Prekonsepsiyonel folik asit ve multivitamin tedavisinin nonsendromik nöral tüp defektlerinin yineleme riski üzerine etkisi. Türkiye Klinikleri Jinekoloji-Obstetrik Dergisi 1999; 9: 183-9.

28. Recommendations for the use of folic acid to reduce the number of cases of spina bifida and other neural tube defects. MMWR Recomm Rep 1992; 41: 1-7.
29. U.S. Preventive Services Task Force. Folic acid for the prevention of neural tube defects: US. preventive services task force recommendation statement. Annals of Internal Medicine 2009; 150: 626-31. [CrossRef]

30. Abdulrazzaq YM, Al-Gazali LI, Bener A, Hossein M, Verghese M, Dawodu A, Folic acid awareness and intake survey in the United Arab Emirates. Reprod Toxicol 2003; 17: 171-6. [CrossRef]

31. Coll O, Pisa S, Palacio M, Quinto L, Cararach V. Awareness of the use of folic acid to prevent neural tube defects in a Mediterranean area. Eur J Obstet Gynecol Reprod Biol 2004; 115: 173-7. [CrossRef]

32. Food and Drug Administration. Food standards: amendment of standards of identity for enriched grain products to require addition of folic acid. Federal Register 1996; 61: 8781-97.

33. Health Canada. Mandatory fortification of flour and pasta with folic acid- Schedule 25, 1998. Regulatory impact analysis statement.

34. The World Health Report. Reducing risks, promoting healthy life. WHO Publications, 2002.

35. Hirsch S, Sanchez H, Albala C, de la Maza MP, Barrera G, Leiva L, et al. Colon cancer in Chile before and after the start of the flour fortification program with folic acid. Eur J Gastroenterol Hepatol 2009; 21: 436-9. [CrossRef]

36. Yajnik CS, Deshpande SS, Jackson AA, Refsum H, Rao S, Fisher DJ, et al. Vitamin B12 and folate concentrations during pregnancy and insulin resistance in the offspring: the Pune Maternal Nutrition Study. Diabetologia 2008; 5: 29-38. 